УДК 37 (091) (177)

DOI: $10.35619 /$ iiu.v1i10.184

\author{
Гринькова Надія \\ кандидат педагогічних наук, доцент, \\ доцент кафедри теорії і методики виховання \\ Рівненського державного гуманітарного університету, \\ м.Рівне, Україна \\ ORCID: 0000-0002-5774-8699 \\ e-mail: nadiia.hrynkova@rshu.edu.ua \\ Стельмашук Жанна \\ кандидат педагогічних наук, \\ доцент кафедри теорії і методики виховання \\ Рівненського державного гуманітарного університету, \\ м.Рівне. Україна \\ ORCID: 0000-0003-2368-4209 \\ e-mail:zhanna.stelmashuk@rshu.edu.ua
}

\title{
АКТУАЛІЗАЦІЯ ІДЕЙ В. СУХОМЛИНСЬКОГО ЩОДО ПІДГОТОВКИ ВЧИТЕЛЯ НОВОЇ УКРАЇНСЬКОЇ ШКОЛИ
}

\begin{abstract}
Анотація. У статті крізь призму завдань Нової української школи актуалізовано педагогічні ідеї Василя Олександровича Сухомлинського (1918-1970) щодо підготовки вчителя. 3'ясовано, що у своїй педагогічній спадщині вчений неодноразово звертався до характеристики основних професійних функцій вчителя як наставника дітей, посередника між дитиною та соціумом. На основі аналізу педагогічних праць В. Сухомлинського виділено та схарактеризовано окремі вимоги щодо особистості педагога, його психолого-педагогічної та фахової підготовки: високий рівень психологічної культури, психолого-педагогічних знань, уміння реалізовувати професійне самопізнання, самовиховання, саморозвиток; висока моральність, яка проявляється у гуманному ставленні до дітей, любові до власної справи. Доведено актуальність поглядів Василя Олександровича Сухомлинського на проблему підготовки педагога в контексті реформаторських ідей Нової української школи. 3'ясовано, що саме він визначив провідні концепти, які лягли в основу побудови Нової української школи, а саме: підготовка висококомпетентних і конкурентоздатних, гуманістично зорієнтованих педагогів, які здатні ефективно виконувати роль коуча, фасилітатора, тьютора, модератора в індивідуальній освітній траєкторії дитини. Констатовано, що мудрі заповіді Великого педагога-практика, педагога-гуманіста $є$ сьогодні дороговказами підготовки вчителя, здатного виховати всебічно розвинену, гармонійну і щасливу особистість.
\end{abstract}

Ключові слова: В. Сухомлинський, педагог, підготовка вчителя, педагогічна спадщина, педагогічні ідеї, Нова українська школа.

Постановка проблеми. Тенденція входження нашої країни в сучасну модель розвитку Європи передбачає наявність нової генерації компетентних спеціалістів, професіоналів, здатних враховувати світові запити та швидко реагувати на зміни в освітньому середовищі. У зв'язку з реалізацією Концепції «Нова українська школа» підготовка висококваліфікованих педагогів набуває особливого значення. Так, безперервний процес еволюційних змін у сучасному освітньому середовищі, оновлення змісту, методів, форм та функцій вчителя висуває перед ним ряд вимог: освіченість, креативність, комунікабельність, справедливість, гуманність, прагнення до 
постійного вдосконалення і поглиблення знань, що $є$ важливою складовою особистої готовності до педагогічної діяльності.

Пошук нових ефективних шляхів підготовки компетентного педагога завжди був пріоритетним завданням освіти і науки, про що свідчать численні доробки і праці в галузі педагогіки та психології. Неодноразово звертався до цієї проблеми В. Сухомлинський у творах «Серце віддаю дітям», «Листи до сина», «Павлиська середня школа», «Сто порад учителеві» та інших. Його практичні рекомендації, поради, методичні розробки є досить цінними в наш час.

3 огляду на висловлені міркування констатуємо, що проблема використання ідей В. Сухомлинського у підготовці вчителя Нової української школи залишається актуальною темою досліджень вітчизняних науковців і педагогів-практиків.

Аналіз останніх досліджень 3 проблеми. Педагогічна спадщина В. О. Сухомлинського була та $\epsilon$ предметом наукових дискусій (М. Антонець, А. Богуш, В. Бондар, Л. Березівська, I. Бех, С. Бричок, Н. Дічек, Л. Заліток, О. Петренко, Н. Побірченко, О. Сухомлинська та ін.).

Питання соціально-педагогічної підготовки майбутніх учителів початкової школи на основі спадщини Василя Олександровича знайшли своє обгрунтування у працях С. Литвиненко, Н. Калініченка, О. Сухомлинської, Т. Поніманської, М. Ярмаченка.

Своєю чергою, І. Бех, О. Петренко, С. Петренко, М. Карпенко, Ю. Міцай вивчали окремі питання формування конкурентоздатного творчого сучасного вчителя, які виокремив і пропагував педагог.

Натомість І. Дичківська досліджувала креативність як складову інноваційної діяльності педагога в контексті ідей В. Сухомлинського.

Таким чином, проведений нами аналіз наукових досліджень та публікацій засвідчив, що окреслена проблема знайшла висвітлення у багатьох джерелах: 3'ясовано зміст та особливості підготовки вчителя у працях Василя Олександровича Сухомлинського. Однак надалі залишаються недостатньо дослідженими ті аспекти, які необхідно враховувати у процесі формування вчителя нової генерації в умовах Нової української школи.

У контексті вищезазначеного метою цієї статті $\epsilon$ актуалізація поглядів В. Сухомлинського щодо підготовки вчителя Нової української школи.

Виклад основного матеріалу дослідження. Провідну роль у створенні школи для дитини Василь Олександрович відводив особистості вчителя, його психологопедагогічній та фаховій підготовці. У своїй педагогічній спадщині вчений неодноразово звертався до характеристики основних професійних функцій учителя як наставника дітей, посередника між дитиною та соціумом. Особистість учителя він розглядав як наріжний камінь навчання та виховання, а його професійну й педагогічну майстерність пов'язував із рівнем психологічної культури, психолого-педагогічних знань, з розмаїттям засобів естетико-психологічного впливу на учнів.

Крім того, педагог зазначав: «Ткач уже через годину бачить плоди своєї праці. Сталевар через кілька годин радіє з гарячого потоку металу - це вершина його мрії, хлібороб через кілька місяців милується колосками, жменею зерна, вирощеного в полі... А вчителеві треба працювати роки і роки, щоб побачити те, що він замислив; ні в кого так часто не гостює почуття незадоволення, як у вчителя...» (Сухомлинський, 1975, c. 171).

Василь Олександрович відстоював гуманістичну позицію педагога, який повинен сприймати дитину такою, якою вона є. Розвиток особистості учня цілком залежить від особистості вчителя. 3 огляду на це традиційно висувають високі вимоги до якостей педагога. Положення про необхідність формування моральних особистих якостей учителя, розроблене В. Сухомлинським, можна розглядати як основу особистісноорієнтованого та компетентнісного підходів, які покладено в основу Концепції «Нова українська школа». 
У багатокомпонентній формулі Нової школи простежується замовлення на вчителя наставника, фасилітатора, консультанта. «Чим більше знає вчитель, писав В. Сухомлинський у праці «Павлиська середня школа», - чим частіше й успішніше відкриває він перед учнями горизонт науки, тим більшу допитливість і жадобу до знань виявляють учні...» (Сухомлинський, 1988, с. 56).

Саме тому вчитель Нової української школи повинен бути здатним швидко реагувати на зміни в освітньому середовищі, бути успішним, умотивованим, компетентним, таким, що має академічну свободу, володіє навичками випереджувального проєктного менеджменту, самостійно й творчо здобуває інформацію, організовує дитиноцентрований освітній процес. Обгрунтовуючи сутність педагогічної професії, В. Сухомлинський неодноразово підкреслював, що «у своїй основі педагогічна праця - це творчість, наближена до наукового дослідження» (Сухомлинський, 1988). Важливою складовою успішної освітньої діяльності у Новій українській школі є підготовка творчого та відповідального вчителя. «Без вдумливого, індивідуального, творчого підходу до кожної людини розв'язати це завдання неможливо, - зазначив В. Сухомлинський у статті «Народний учитель». - У цій справі найстрашніше - формалізм, надія на якісь універсальні форми і методи виховання (Сухомлинський, 1977 a, с. 182).

Сучасні діти потребують педагога творчого, без шаблонного мислення, педагогаінноватора. На думку Василя Олександровича, для цього вчитель має бути справжнім скульптором, який працює 3 найскладнішим матеріалом - ЛЮДИНОЮ. Він писав: «...Ви переступили поріг школи, вирішили присвятити своє життя вихованню людини... Пам'ятайте - ви один зі скульпторів, що творять людину майбутнього. I скульптор особливий, не схожий на інших. Виховання - творення Людини - ваша професія» (Сухомлинський, 1977 а, с. 46).

Учитель сьогодні покликаний будувати, проектувати, втілювати особистісноорієнтовану модель освіти, ключові положення якої були розроблені у працях педагога.

Запорукою результативного навчання Великий Педагог вважав людяність, любов, доброту, чуйність, сердечність і тактовність стосовно учнів. «Пам'ятайте, - писав Василь Олександрович у статті «Залежить тільки від нас», - що кожна дитина приходить у школу зі щирим бажанням добре вчитися, Воно ніби яскравий вогник, що освітлює світ дитячих турбот і тривог. Дитина несе його нам, учителям, з безмежною довірливістю. Цей вогник легко погасити різкістю, грубістю, байдужістю, невірою в неї, дитину» (В. Сухомлинський, 1977 b, с. 285). Базовими духовно-моральними цінностями у програмі «Нова українська школа» у поступі до цінностей» визначені любов, повага до інших, гідність, відповідальність, совість, свобода, толерантність, справедливість, рівноправ'я, ініціативність. Вони мають стати чи не провідними орієнтирами роботи сучасного учителя (Інститут проблем виховання, 2018). Василь Олександрович переконував: «Головне, - це віра в людину, чутливість до всього хорошого в ній. Висока моральність учителя стає нині найважливішою умовою його педагогічної майстерності... Улюбленим і авторитетним учитель стає не тільки тому, що досконало знає свій предмет, а й тому, що, глибоко люблячи його, поєднує у своєму серці цю любов 3 любов'ю до людини-дитини» (Сухомлинський, 1977 b, с. 15). Педагог без любові до дитини - це все одно, що співак без голосу, музикант без слуху, живописець без відчуття кольору. Щоб слова вчителя дійшли до сердець дітей, потрібна духовна спільність, взаємне довір'я, відвертість, доброзичливість, «що можна порівняти 3 тонким, ледве чутним звучанням струни, коли рука музиканта торкнеться інструмента. Як це нелегко i важливо - досягти гармонійного звучання найчутливішого, трепетного, живого інструмента - дитячої душі!..» (Сухомлинський, 1977 b, c. 15).

Ще однією важливою вимогою до вчителя $\epsilon$ вимога любові до власної справи. «Щоб знайти в кожному учневі найсильнішу його сторону, відкрити в ньому золоту 
жилку, - писав В. Сухомлинський у статті «Суспільство і вчитель», - всі вчителі повинні бути людьми, пристрасно закоханими в свою працю, що вміють запалити вогник такої самої любові у своїх вихованців» (Сухомлинський, 1977 с, с. 142). «3 вуст учителя, - пояснив Великий Педагог в іншій праці «Павлиська середня школа», дитина часто чує моральні повчання і настанови. Все це набуває авторитету в очах дитини, оскільки вона, дитина, бачить у своєму вчителеві людину, одухотворену своєю працею, закохану в свою працю» (Сухомлинський, 1977 с, с. 383).

Суттєвою вимогою до особистості педагога $є$ наявність високих моральних якостей. «Вирішальне значення має те, - зазначив Василь Олександрович у праці «Народження громадянина», - яких людей побачить у нас підліток. Ми мусимо бути для підлітків зразком багатства духовного життя; лише за цієї умови ми маємо моральне право виховувати» (Сухомлинський, 1977 с, с. 383).

Освітньою реформою передбачено безперервне особистісне і професійне зростання кожного педагога (2016). Своєю чергою Великий Педагог вказував на особливу роль умінь учителя щодо професійного самопізнання і самовиховання. «Щоб бути для учнів джерелом знань, учитель завжди повинен перебувати в атмосфері багатого, цікавого, багатогранного духовного життя» (Сухомлинський, 1977 с, с. 37).

Метою освіти в Новій українській школі $\epsilon$ всебічний та гармонійний розвиток особистості відповідно до ії психофізіологічних особливостей, інтересів, потреб. Отже, учитель має бути готовим втілити цю мету в життя. А це спроможний зробити педагог, здатний відчувати, розуміти та приймати дитину такою, якою вона $\epsilon$. «Виховання всебічно розвиненої особистості - це вміння розібратися у великій кількості найскладніших і немовби непомітних на перший погляд залежностей, - зауважував В. Сухомлинський у праці «Проблеми виховання всебічно розвиненої особистості». Бути мудрим вихователем - означає насамперед розуміти причинно-наслідкові зв'язки в усьому, що ми повсякденно бачимо, робимо, чого ми чекаємо. «Мудрість влади педагога - це передусім його здатність усе зрозуміти...» (Сухомлинський, 1976, с. 55).

Учитель насамперед, як уважав В.Сухомлинський, повинен уміти пізнавати духовний світ дитини, розуміти в кожній дитині «особисте»: «Немає у світі нічого складнішого й багатшого людської особистості. I саме до особистості звернений педагог у своїй діяльності, тому вчитель - це людина, яка не тільки опанувала теорію педагогіки, вона ще і практик, який відчуває дитину, вона мислитель, який з'єднує теорію та практику воєдино» (Сухомлинський, 1988, с. 267).

Василь Олександрович пояснював: «Боляче бачити, що навіть у вчителів, які знають свій предмет, виховання іноді перетворюється на жорстку війну тільки тому, що ніякі духовні ниті не зв'язують педагога з учнями, і душа людини - застебнута на всі гудзики сорочка. Головна причина потворних, неприпустимих стосунків між наставником і вихованцем, що мають місце в окремих школах - це взаємна недовіра і підозра; іноді вчитель не відчуває таємних порухів дитячої душі, не переживає дитячих радостей і прикрощів, не намагається в думці поставити себе на місце дитини» (Сухомлинський, 1977 с, с. 4).

Відповідаючи на запитання «Що значить хороший учитель?», педагог підкреслював, що це, перш за все, людина, яка любить дітей, знаходить радість у спілкуванні з ними, вірить у те, що кожна дитина може стати доброю людиною, вміє дружити $з$ дітьми, бере близько до серця дитячі радощі й прикрощі, знає душу дитини, ніколи не забуває, що і сам він був дитиною (Сухомлинський, 1988, с. 40).

У цілому результати роботи педагога можна оцінити за тим, скільки успішних і щасливих дітей він зумів виховати. Тому сьогодні, як ніколи, актуальним і таким, що не викликає сумніву, є твердження педагога про те, що «Дитина має бути щасливою вже сьогодні». Василь Олександрович пояснював: «Дитинство - найважливіший період людського життя, не підготовка до майбутнього життя, а справжнє, яскраве, самобутнє неповторне життя...», - писав видатний педагог і наголошував, що саме «у дитинстві закладається людський корінь. Жодної рисочки природа не відшліфовує - 
вона тільки закладає, а відшліфовувати нам - батькам, педагогам, суспільству» (Сухомлинський, 1977 с, с. 421).

Висновки і перспективи подальших розвідок. Гортаючи сторінки геніальних праць Василя Олександровича Сухомлинського, хочеться зазначити, що в сучасних умовах реформування освітньої системи теоретичні та методичні ідеї педагогагуманіста залишаються актуальними. Саме він визначив провідні концепти, які лягли в основу побудови Нової української школи, а саме: підготовка висококомпетентних і конкурентоздатних, гуманістично зорієнтованих педагогів, які здатні ефективно виконувати роль учителя - не як єдиного наставника та джерела знань, а як коуча, фасилітатора, тьютора, модератора в індивідуальній освітній траєкторії дитини.

Отже, мудрі заповіді Великого педагога-практика, педагога-гуманіста є сьогодні дороговказами підготовки вчителя, здатного виховати всебічно розвинену, гармонійну і щасливу особистість.

\section{СПИСОК ВИКОРИСТАНИХ ДЖЕРЕЛ}

Сухомлинский, В. (1975). Как воспитать настоящего человека. (Советь воспитателям). Київ: Радянська школа. 236 с.

Сухомлинський, В. (1988). Сто порад учителеві. Київ: Радянська школа. 310 с.

Інститут проблем виховання, Інститут модернізації змісту освіти (2018). Програма «Нова украӥнська школа» у поступі до чінностей. Київ. 40 с.

Сухомлинський, В. (1977 а). Вибрані твори в 5 m. Т.4: Павлиська середня школа. Розмова з молодим директором. Київ: Радянська школа. 640 с.

Сухомлинський, В. (1977 b). Вибрані твори в 5 m. T. 5: Статті. Київ: Радянська школа. 639 с.

Сухомлинський, В. (1977 с). Вибрані твори: В 5 m. Т. 3: Серие віддаю дітям. Народження громадянина. Листи до сина. Київ: Радянська школа. 670 с.

Кабінет Міністрів України, (2016). Концепція «Нова українська школа» [online]. Режим доступу на: https://mon.gov.ua/ua/tag/nova-ukrainska-shkola [Дата останнього звернення 02 жовтня 2019].

Сухомлинський, В. (1976). Вибрані твори в 5 m. Т.1: Проблеми виховання всебічно розвиненої особистості Київ: Радянська школа. С. 55-206.

\section{REFERENCES}

Sukhomlinskiy, V. (1975). Kak vospitat nastoyashchego cheloveka (Sovety vospitatelyam) [How to Bring up the True Man. (Advice to Teachers)]. Kyiv: Radianska shkola. (in Russian)

Sukhomlynskyi, V. (1988). Sto porad uchytelevi [One Hundred Tips for Teacher]. Kyiv: Radianska shkola. (in Ukrainian)

Institute of problems of education, Institute of modernisation of maintenance of educatio. (2018). Prohrama Nova ukrainska shkola u postupi do tsinnostei [Program New Ukrainian School in Moving Toward Values]. Kyiv. (in Ukrainian)

Sukhomlynskyi, V. (1977 a). Vybrani tvory: T. 4 [Selected Works. Vol.4]. Kyiv: Radianska shkola. (in Ukrainian)

Sukhomlynskyi, V. (1977 b). Vybrani tvory: T. 5 [Selected Works. Vol.5]. Kyiv: Radianska shkola. (in Ukrainian)

Sukhomlynskyi, V. (1977 c). Vybrani tvory: T. 3 [Selected Works. Vol.3]. Kyiv: Radianska shkola. (in Ukrainian)

Cabinet of Ministers of Ukraine. (2016). Kontseptsiia "Nova ukrainska shkola" [Conception "New Ukrainian School"] [online]. Rezhym dostupu: https://mon.gov.ua/ua/tag/nova-ukrainska-shkola [Data ostanoho zvernennia 9 travnia 2019]. (in Ukrainian)

Sukhomlynskyi, V. (1977). Vybrani tvory: T. 1 [Selected Works. Vol 1]. Kyiv: Radianska shkola. (in Ukrainian) 


\title{
ACTUALIZATION OF V.O. SUKHOMLYNSKYI'S IDEAS ON TRAINING A TEACHER OF THE NEW UKRAINIAN SCHOOL
}

\author{
Nadiia Hrynkova \\ Candidate of Pedagogical Sciences, Associate Professor, \\ Associate Professor at the Department of Theory and Methodology of Education, \\ Rivne State University for the Humanities, \\ Rivne, Ukraine \\ ORCID: 0000-0002-5774-8699, \\ e-mail: nadiia.hrynkova@rshu.edu.ua \\ Zhanna Stelmashuk \\ Candidate of Pedagogical Sciences, \\ Associate Professor at, the Department of Theory \\ and Methodology of Education, \\ Rivne State University for the Humanities, \\ Rivne, Ukraine \\ ORCID: 0000-0003-2368-4209, \\ e-mail: zhanna.stelmashuk@rshu.edu.ua
}

\begin{abstract}
In the article the pedagogical ideas of Vasyl Olexandrovych Sukhomlynskyi (1918-1970) on training teacher in the context of the New Ukrainian School are actualized. It was found that in his pedagogical heritage, the scientist repeatedly referred to the characterization of the main professional functions of a teacher as a mentor of children, mediator between a child and society. On the basis of the analysis of pedagogical works of V.O. Sukhomlinsky individual requirements for the personality of the teacher, his psychopedagogical and professional training were identified and characterized: high level of psychological culture, psychological and pedagogical knowledge, ability to realize professional self-knowledge, self-education, self-development; high-morality that appear in humane attitude toward children, to own business. It is proved that the purpose of education concerning to the New Ukrainian School is a comprehensive and harmonious development of the individual in accordance with his psychophysiological peculiarities, interests, needs. That is why the teacher should be ready to realize this purpose. It is able to make a teacher, able to feel, understand and accept the child as she is, to believe in her power and opportunities to reach her potential.

The relevance of Vasyl Sukhomlynskyi's views on the problem of teacher training in the context of the reform ideas of the New Ukrainian school is proved. It has been found out that he identified the leading concepts that underpin the construction of the New Ukrainian School, namely: the preparation of highly competent and competitive, humanistic oriented teachers, who are able to effectively fulfill the role of coach, facilitator, tutor, moderator of a person. It is determined that the results of the teacher's work can be estimated by the number of successful and happy children he brought up, which is why today, as never before, is relevant and unquestionable, the teacher's statement that "A child should be happy today". It is stated that the wise advice of the Great Teacher, Humanist, Scholar are today the roadmaps for the preparation of a teacher, who is capable of cultivating a well-developed, harmonious and happy personality.
\end{abstract}

Keywords: V. O. Sukhomlynskyi, teacher, training of teacher, pedagogical heritage, pedagogical ideas, New Ukrainian school.

Стаття надійшла до редакиї 09.10. 2019 р. 